\title{
Bone Mineral Density Test
}

National Cancer Institute

\section{Source}

National Cancer Institute. Bone Mineral Density Test. NCI Thesaurus. Code C61545.

A scanning procedure used to measure calcium and other minerals present in bone. 